\title{
PERSPEKTIF TINGKAT KEMAMPUAN DAN TRANSFORMASI WIRAUSAHAWAN MERUBAH RISIKO MENJADI SUKSES BERWIRAUSAHA
}

\author{
Tedy Ardiansyah \\ Universitas Indraprasta PGRI, Indonesia \\ Email: tedy.ardiansyah@unindra.ac.id
}

Diterima: Juni 2018; Disetujui: Juli 2018; dipublikasikan: Agustus 2018

\begin{abstract}
ABSTRAK
Tujuan penelitian ini untuk mengetahui Tingkat kemampuan dan transformasi wirausahawan didalam proses merubah suatu kendala atau risiko menjadi keuntungan atau kesukseskan dari peristiwa-peristiwa yang telah dilakukan, metode penelitian menggunakan penelitian dengan pendekatan deskriptif kualitatif, dimana peneliti ingin mengeksplor fenomena - fenomena yang tidak dapat dikuantifikasikan yang bersifat deskriptif. Secara umum alasan risiko untuk menjadi wirausahaan dibagi menjadi 5 bagian yaitu: 1.Tidak mempunyai pengalaman baru, 2. Tidak mempunyai modal, 3. Tidak mempunyai keberanian, 4. Tidak ada orang yang menuntun dan 5. Takut keluar dari zona nyaman. Risiko tersebut diatas dapat diatasi dengan tingkatan kemampuan dan Transformasi wirausahawan, untuk Tingkat kemampuan antara lain: 1. Risk Averter (menghindar dari risiko), 2. Comfort Risk Calculation Taker (orang yang menghitung risiko yang terjadi harus lebih kecil dari keuntungan yang ia peroleh), 3. Risk Calculation Taker (berani mengambil risiko usaha dengan perhitungan aman) 4. Risk Manager (manajer risiko bagi dirinya) 5. Risk Taker (Pengambil Risiko), serta Transformasi kewirausahaan yaitu 1.Pola pikir \& paradigm, 2.Visioner (Kreatif \& inovasi), 3.Owner, dan terakhir 4.Investor. Hasil kesimpulan bahwa tingkat kemampuan dan Transformasi wirausahwan dapat merubah risiko menjadi suskses berwirausaha. Kesimpulan dari penelitian ini bahwa Tingkat kemampuan dan transformasi wirausahawan mempunyai korelasi perubahan risiko menjadi kesuksesan.
\end{abstract}

Kata kunci: Kewirausahaan, Tingkat Kemampuan, Transformasi, Risiko, Kesuksesan

\begin{abstract}
The purpose of this study to determine the level of entrepreneurial ability in the process of changing a constraint or risk into profit or the success of the events that have been done, research methods using research with qualitative descriptive approach, where researchers want to explore phenomena - phenomena that can not be calculated and is descriptive. In general, the reasons for the risks of becoming an entrepreneur are divided into 5 sections: 1 . No new experience, 2. No capital, 3. No courage, 4. No guiding person and 5. Fear of getting out of comfort zone. The above risks can be overcome with the level of entrepreneurial ability, the level of ability classified as follows: 1. Risk Averter (avoid the risk), 2. Comfort Risk Calculation Taker (people who calculate the risk should be less than the gain he earned), 3 Risk Calculation Taker (risk taking business with safe calculation) 4. Risk Manager (risk manager for him) 5. Risk Taker (Risk Taker). The conclusion that the level of ability of entrepreneurs can change the risk of becoming an entrepreneurial susceptible.
\end{abstract}

Keywords: Entrepreneurs, Entrepreneurial, Transformation, Risk, Success 


\section{Sosio e-kons}

Volume 10, No. 2, Agustus 2018, pp. 165-178

e-ISSN: 2502-5449

p-ISSN: 2085-2266

http://journal.lppmunindra.ac.id/index.php/sosio_ekons

\section{PENDAHULUAN}

Jumlah wirausaha di Indonesia hanya berkisar 3\%, semua pihak harus mengoptimalkan fungsi kewirausahaan sebagai gerakan ekonomi rakyat. Dengan peran serta berbagai pihak hal ini akan meningkatkan rasio wirausaha di Indonesia yang saat ini presentasinya masih sangat rendah. Secara presentase, jumlah wirausaha di negara Indonesia hanya sekitar 3\%, kalah dari negara tetangga di ASEAN seperti Malaysia, Singapura, dan Thailand yang sudah diatas 4\%.(okezone, 2018).

Baru 1, 65 persen atau hanya 1,95 juta orang dari angkatan kerja yang menjadi wirausaha di Indonesia. Badan Pusat Statistik (BPS) mencatat, jumlah angkatan kerja di Indonesia pada Agustus 2013, mencapai 118, 2 juta orang atau bertambah 140 ribu orang dibandinkan dengan periode tahun sebelumnya. Dari seluruh angkatan kerja tersebut, jumlah penduduk yang bekerja pada Agustus 2013 sebanyak 110, 8 orang

Kesadaran berwirausaha penduduk Indonesia masih sangat rendah. Bagi sebagian mereka yang bekerja pada instansi swasta maupun pemerintah sudah merasa nyaman dengan menerima gaji rutin setiap bulan. Berapapun besarnya gaji yang diterima, mereka syukuri. Mereka berpikir diluar sana masih banyak orang yang tidak seberuntung dirinya. Ada banyak hal yang mereka pertimbangkan saat untuk memutuskan resign dari pekerjaan tetapnya dan memilih untuk berwirausaha. Contoh terbatasnya modal, bingung menentukan jenis usaha yang akan dijalankan, relasi bisnis masih terbatas, hingga perasaan takut gagal. (viva.co.id, 2018).

Beberapa hambatan yang pada umumnya sering terjadi ketika seseorang sedang memulai sebuah bisnis. Harapannya nanti, dari kendala ini bisa kita pelajari bersama, apa yang harus dilakukan, solusi seperti apa yang akan kita pilih ketika ada kendala-kendala yang menghambat bisnis kita. Syukur-syukur ada juga yang mau membagikan pengalaman yang menjadi kendalanya selama ini dalam mengelola sebuah bisnis lebih baik lagi sekaligus membagikan formulanya. berikut kendala-kendalanya :

\section{Sulit untuk mendapatkan modal}

Memang untuk menjalankan suatu bisnis tidak harus melulu membutuhkan modal. Bisnis dropshipperan juga bisa dikatakan tanpa memerlukan modal. Kita hanya perlu skill menjual. Namun bagaimanapun sebagai pemula yang baru akan menjalankan bisnis. Saya justru lebih setuju jika harus mengeluarkan modal untuk menjalankan bisnis. Tujuannya apa? Agar ada semangat untuk mengejar profit. Saya katakan tidak mungkin seorang wirausaha tidak membutuhkan profit. Jadi, jika serius untuk berwirausaha, harus siap modal terlebih dahulu.

\section{Ikut-ikutan dan akhirnya tidak fokus}

Kebanyakan kasus "ikut-ikutan" ini adalah terjadi pada Mahasiswa yang masih mempunyai jiwa semangat untuk berbisnis. Dan pada umumnya suka mengikuti trend yang sedang berkembang. Ketika trend sudah mulai pudar maka akan mencoba fokus untuk bisnis lainnya. Menjalankan sebuah bisnis tidak bisa dilakukan setengah-setengah. Harus fokus dan totalitas.

\section{Mudah menyerah}

Memulai sebuah usaha atau bisnis, sepertinya tidak akan langsung bisa sukses. Jatuh bangun diawal merintis sebuah usaha sudah pasti ada. Jadi jangan mudah menyerah, terus belajar dari kesalahan yang ada. Meskipun usaha Anda sudah bisa berjalan sempurna, saya yakin pasti Anda akan tetap menemukan hambatan.

\section{Salah perhitungan biaya orperasional di awal}

Saat kita memulai sebuah bisnis baru, biasanya yang sering terjadi adalah membelanjakan modal untuk membeli berbagai macam biaya operasional ataupun perlengkapan usaha yang 
sekiranya bisa jadi belum terlalu dibutuhkan. Atau bisa jadi Anda melakukan belanja promosi untuk usaha Anda. Tanpa disadari terlalu banyak melakukan promosi dibandingkan produksi ujung-ujungnya nanti orang akan banyak yang tahu tentang produk Anda, namun produk yang Anda miliki stock nya limit.(Bukalapak, 2014).

Hal tersebut diatas menjadi suatu gap sehingga kebanyakan orang cenderung tidak mau berwirausaha atau sudah berwirausaha tetapi mengalami kegagalan hal ini sangat berkorelasi dengan tingkat kemampuan dan transformasi dalam aktivitas melakukan wirausaha.

Tujuan penelitian ini untuk mengetahui Tingkat kemampuan dan transformasi wirausahawan didalam proses merubah suatu kendala atau risiko menjadi keuntungan atau kesukseskan dari peristiwa-peristiwa yang telah dilakukan, metode penelitian menggunakan penelitian dengan pendekatan deskriptif kualitatif, dimana peneliti ingin mengeksplor fenomena - fenomena yang tidak dapat dikuantifikasikan yang bersifat deskriptif.

Permasalahan modal, bingung menentukan jenis usaha yang akan dijalankan, relasi bisnis masih terbatas, perasaan takut gagal dalam berwirasuha dan risiko kegagalan lainnya tersebut dapat diatasi dengan meningkatkan tingkat kemampuan kewirausahaan. Tingkatan kemampuan kewirausahaan seseorang dibagi menjadi 5 tingkat (Hendro, 2011) yaitu:

1. Tingkat kemampuan dalam menghadapi rasa takut kecil sekali sehingga ia cenderung menghindari risiko.

Tingkat ini disebut menghindar dari risiko (avoid a risk). Orang menyebutnya risk averter. Ciri-cirinya adalah a.) Senang mempertahankan rasa kenyamanan (comfort zone), anda dimana anda selalu ingin menikmati keadaan saat ini yang menghanyutkan diri anda. b.) Selalu melihat kesulitan didepan mata bukan kemampuannya. Orang yang pesimis bukan optimis. c.) Melihat risiko dengan rasa takut atau bersifat risk phobia d.) Pemalas dan enggan bekerja e.) Banyak alasan untuk menghindari kerja keras f.) Berusaha untuk menutupi rasa takutnya, orang tipe risk averter ini lebih senang memilih situasi: menganggur, tidak ada kerjaan yang berat, bekerja dengan hasil yang instan dan tidak mau menggunakan pengetahuan dan ketrampilannya untuk meraih hasil yang baik.

2. Tingkat kemampuan dalam menghadapi rasa takut ada dan ia selalu menggunakan pengetahuannya untuk bekerja lebih baik lagi.

Tingkat ini disebut comfort risk calculation taker (orang yang menghitung risiko yang terjadi harus lebih kecil dari keuntungan yang ia peroleh). Oleh sebab itu, orang pada tingkatan ini berorientasi hanya mencari pekerjaan yang nyaman, aman dari PHK atau biasa-biasa saja. Ciri-cirinya adalah: a.) Senang bekerja tetapi nyaman dan aman. b.) Mengedepankan keuntungan terlebih dahulu daripada kerugian. Padahal belum tentu demikian. c.) Tidak berpandangan jauh dan melihat masa lalu sebagai acuan untuk berpikir saat ini (past oriented) d.) Berpikir selalu realistis (kenyataan), bukan futuristis (masa depan), sehingga bukan tipe orang yang visioner. Orang tipe ini lebih senang: Mencari kerja yang terkadang mempunyai risiko di PHK tetapi ia berkata lebih aman bekerja daripada berwirausaha, mencari kerja sebagai pegawai yang ada tunjangan pensiunnya, walaupun dimasa mendatang nilainya sudah tidak berarti lagi untuk kehidupannya dan berpikir cukup (menerima apa adanya) tetapi tidak ada kemampuan berpikir untuk mencari sesuatu yang lebih baik lagi.

3. Tingkat kemampuan kewirausahaan dalam menghadapi rasa takutnya lebih tinggi dan ia memiliki keberanian untuk menanggung atau mengatasi risiko kegagalan. Ia berani menghadapi rasa takutnya karena ia merasa mampu, memiliki pengetahuan dan pengalaman kerja yang sesuai dengan apa yang ia kerjakan dalam bisnisnya. Tingkatan ini disebut risk calculation taker atau berani mengambil risiko usaha dengan perhitungan aman. Ciri-cirinya adalah: a.) Berani mengambil keputusan untuk berwirausaha bila ia mampu melakukannya berdasarkan keahlian, pengalaman dan pengetahuannya (latar belakang pendidikan) b.) Ia selalu bekerja secara individu dalam mengelola usahanya dan mengambil keputusan. c.) Bisnis dan usahanya tidak atau belum dikelola secara organisasional. d.) Usahanya sangat dipengaruhi oleh waktunya 


\section{sosio e-kons}

Volume 10, No. 2, Agustus 2018, pp. 165-178

e-ISSN: 2502-5449

p-ISSN: 2085-2266

http://journal.lppmunindra.ac.id/index.php/sosio_ekons

sendiri. e.) Memiliki pandangan jauh kedepan. f.) Sudah bias bekerja secara kontinyu. g.) Ingin menjadi 'bos' bagi dirinya sendiri. h.) Masih berpikir realistis

4. Tingkat kemampuan kewirausahaan dalam menghadapi rasa takut lebih kompleks

Khususnya dalam hal memperhitungkan, mengendalikan, mengatasi, dan menanggung risiko kegagalan usahanya disbanding dengan ketiga tingkatan diatas. Ia berani mengalahkan dan mengatasi rasa takutnya bukan hanya karena pengetahuan, ketrampilan dan pengalamannya saja tetapi lebih kompleks dari itu.Biasanya jenis usaha yang diambil dan dimulainya lebih berskala industri. Orang pada tingkatan ini disebut manajer risiko bagi dirinya (risk manager). Ciri-cirnya adalah: a.) Mengambil keputusan dari berbagai sisi, risiko, informasi dan kondisi untuk suatu nilai (value) yang lebih optimal dan tepat, bukan karena minimal saja. b.) Ada unsur visioner, yang sering tidak terlihat dari keputusan yang ia ambil, sehingga cenderung berkata itu keputusan nekat. c.) Mempunyai mimpi dan orientasi bisnis berskala besar atau skala industry 5. Tingkat kemampuan kewirausahaan dalam menghadapi rasa takutnya sangat tinggi, artinya dalam hal mengatasi rasa takut akan kegagalan yang cukup besar, ia cenderung mengambil keputusan menggunakan intuisinya yang sangat kuat sekali, bahkan bisa cenderung sedikit mengadu keberuntungan. Orang pada tingkatan ini disebut risk taker atau pengambil risiko. Tingkatan ini bisa dikelompokan menjadi 2 jenis, yaitu: a.) Tingkat risk taker yang lebih realistis dan analistis. Sering disebut juga Investor atau penanam modal yang menjadi wirausahawan dengan tujuan memiliki saham (kepemilikan perusahaan) atas sebuah perusahaan dalam jumlah tertentu untuk mendapatkan keuntungan baik berupa dividen (pembagian laba kepada pemegang saham sesuai proporsinya) atau kenaikan nilai saham apabila saham tersebut dijual kembali kepada orang lain. b.) Tingkat risk taker yang bersifat intuisi dan menggunakan persaannya (feeling) semata. Ini disebut gambler atau berjudi, tetapi jenis ini tidak termasuk kategori tingkat kewirausahaan karena tidak bersifat bisnis dan mengarah pada hobi saja.

Dari risiko tersebut diatas, dari hasil beberapa penelitian juga telah memperkuat hambatan tersebut dimana disesuaikan dengan tingkat kemampuan kewirausahaan, contohnya antara lain: Penelitan yang dilakukan di daerah padang, dimana masalahnya adalah pada Faktor internal yang menghambat pengrajin sulaman berwirausaha adalah tugas-tugas sebagai ibu rumah tangga, masa kehamilan dan tugas menjaga anak. Sementara dari segi emosional adalah kesulitan dalam mengambil keputusan karena terlalu banyak pertimbangan. Selain itu kondisi perasaan dan hubungan antara laki-laki dan perempuan dalam sebuah usaha mengganggu konsentrasi mereka dalam berbisnis. Dan yang ke 2 (Dua) Untuk faktor eksternal faktor sosial budaya yang menghambat pengrajin wanita di Jorong Lundang dalam berwirausaha adalah anggapan masyarakat bahwa yang mencari nafkah adalah kaum perempuan. Selain itu juga hambatan dari segi budaya mingkabau. Selain itu hambatan dari segi administrasi muncul dari sulitnya mendapatkan bantuan modal dan birokrasi yang berbelit- belit.(Rahmidani, 2014).

Tingkat kemampuan Berwirausaha tentu juga harus dilandasi dengan proses transformasi dalam melakukan kewirausahaan, ada 4 (empat) jenis tahapan proses transformasi dalam entrepreneurship (Hendro, 2011) yaitu: 1. Transformasi pola pikir (mindset) dan paradigm (paradigm), yaitu sebuah transformasi pemikiran, sikap, motif, semangat, dan karakter yang lama untuk berubah menjadi seorang yang berpikiran sama dengan seorang entrepreneur yang cerdas. 2. Transformasi cara berpikir yang lama untuk berubah dari kebiasaan yang selalu menggunakan logika ke pola pikir kreatif dalam menemukan inspirasi, ide, dan peluang bisnis. Cara berpikir yang perlu ditransformasi adalah menghindari jebakan logika, berpikir berbeda dengan orang(umum), menjadikan pengetahuan sebagai 'perkakas' dalam menemukan inspirasi melalui pola pikir yang kreatif dan inovatif serta berpikir visioner. 3. Transformasi entrepreneurial dari bersikap sebagai entrepreneur (owner) menjadi manajer pengelola bisnis (intrapreneur atau entrepreneurial organization) yang professional. Menjadi entrepreneur yang berpikir sebagai pemilik, pendiri, dan penggagas sebuah bisnis itu berbeda dengan intrapreneur yang bertindak sebagai pengelola, manajer, pemimpin dan pelaksana strategi yang bertujuan untuk mewujdukan visi dan misi pendiri bisnis. 4. Transformasi entrepreneurial dari pola pikir 


\section{sosio e-kons}

Volume 10, No. 2, Agustus 2018, pp. 165-178

e-ISSN: $2502-5449$

p-ISSN: 2085-2266

http://journal.lppmunindra.ac.id/index.php/sosio_ekons

sebagai investor. Setelah seorang pebisnis itu sukses, pola pikirnya berkembang ingin menjadi seorang investor untuk mengembangkan bisnisnya melalui ekspansi bisnis, membeli bisnis, franchise bisnis, dan meningkatkan nilai-nilai perusahaan hingga mengarah pada peningkatan nilai asset riil yang tinggi secara tangible dan itangible sehingga sebuah perusahaan tidak dinilai dari asset riil tetapi telah berubah menjadi sebuath asset yang tidak ternilai harganya.

Dari beberapa pendapat sebelumnya, Suryana (2006) menyimpulkan beberapa karakter umum kewirausahaan, yaitu sebagai berikut (Prof Dr. Sama'un Jaja Raharja, 2008):

1. Memiliki Motif Berprestasi Tinggi Seorang wirausaha selalu berprinsip bahwa apa yang dilakukan merupakan usaha optimal untuk menghasilkan nilai maksimal. Artinya, wirausaha melakukan sesuatu hal secara tidak asal-asalan, sekalipun hal tersebut dapat dilakukan oleh orang lain. Nilai prestasi merupakan hal yang justru membedakan antara hasil karyanya sebagai seorang wirausaha dengan orang lain yang tidak memiliki jiwa kewirausahaan. Dorongan untuk selalu berprestasi tinggi harus ada dalam diri seorang wirausaha, karena dapat membentuk mental yang ada pada diri mereka untuk selalu lebih unggul dan mengerjakan segala sesuatu melebihi standar yang ada. Indikator memiliki motif berprestasi tinggi dalam kehidupan sehari-hari dapat tercermin pada: a. mahasiswa yang tekun belajar untuk mencapai Indeks Prestasi Kumulatif (IPK) tertinggi; b. Bill Gates, pendiri dan pemilik Microsoft, mempunyai ambisi untuk selalu menjadi nomor satu. Saat kelas 4, ketika harus menulis laporan sepanjang 4-5 halaman tentang bagian tubuh manusia, ia membuat laporan tersebut lebih panjang beberapa kali lipat.

2. Memiliki Perspektif ke Depan Sukses adalah sebuah perjalanan, bukan tujuan. Setiap saat mencapai target, sasaran, atau impian, maka harus segera membuat impian-impian baru yang dapat memacu serta memberi semangat dan antusiasme untuk mencapainya. Arah

3. Memiliki Kreativitas Tinggi Seorang wirausaha umumnya memiliki daya kreasi dan inovasi yang lebih dari nonwirausaha. Hal-hal yang belum terpikirkan oleh orang lain sudah terpikirkan olehnya dan wirausaha mampu membuat hasil inovasinya tersebut menjadi permintaan.

4. Memiliki Sifat Inovasi Tinggi Seorang wirausaha harus segera menerjemahkan mimpimimpinya menjadi inovasi untuk mengembangkan bisnisnya. Jika impian dan tujuan hidup merupakan fondasi bangunan hidup dan bisnis, maka inovasi dapat diibaratkan sebagai pilar-pilar yang menunjang kukuhnya hidup dan bisnis. Setiap impian harus diikuti dengan inovasi sebagai kerangka pengembangan, kemudian diikuti dengan manajemen produk, manajemen konsumen, manajemen kas, sistem pengendalian, dan sebagainya. Inovasi adalah kreativitas yang diterjemahkan menjadi sesuatu yang dapat diimplementasikan dan memberikan nilai tambah atas sumber daya yang kita miliki. Jadi, untuk senantiasa dapat berinovasi, kita memerlukan kecerdasan kreatif. Sifat inovatif dapat ditumbuhkembangkan dengan memahami bahwa inovasi adalah suatu kerja keras, terobosan, dan kaizen (perbaikan yang terus- menerus). Contoh perilaku inovasi tinggi di antaranya: stasiun televisi berlomba-lomba menciptakan program acara baru untuk menarik minat penonton guna mendapat dukungan dari para sponsor iklan.

5. Memiliki Komitmen terhadap Pekerjaan Berdasarkan pendapat Sony Sugema, terdapat tiga hal yang harus dimiliki oleh seorang wirausaha yang sukses, yaitu mimpi, kerja keras, dan ilmu. Ilmu disertai kerja keras namun tanpa impian bagaikan perahu yang berlayar tanpa tujuan. Impian disertai ilmu namun tanpa kerja keras ibarat seorang pertapa. Impian disertai kerja keras, tanpa ilmu, ibarat berlayar tanpa nakhoda, tidak jelas ke mana arah yang akan dituju. Sering kali orang berhenti di antara sukses dan kegagalan. Namun, seorang wirausaha harus menancapkan komitmen yang kuat dalam pekerjaannya, karena jika tidak akan berakibat fatal terhadap segala sesuatu yang telah dirintisnya

6. Memiliki Tanggung Jawab Ide dan perilaku seorang wirausaha tidak terlepas dan tuntutan tanggung jawab. Oleh karena itu, komitmen sangat diperlukan dalam pekerjaan sehingga 


\section{Sosio e-kons}

Volume 10, No. 2, Agustus 2018, pp. 165-178

e-ISSN: 2502-5449

p-ISSN: 2085-2266

http://journal.lppmunindra.ac.id/index.php/sosio_ekons

mampu melahirkan tanggung jawab. Indikator orang yang bertanggung jawab adalah berdisiplin, penuh komitmen, bersungguh-sungguh, jujur, berdedikasi tinggi, dan konsisten

7. Memiliki Kemandirian atau Ketidaktergantungan terhadap Orang Lain Orang yang mandiri adalah orang yang tidak suka mengandalkan orang lain namun justru mengoptimalkan segala daya dan upaya yang dimilikinya sendiri. Intinya adalah kepandaian dalam memanfaatkan potensi dan tanpa harus diatur oleh orang lain. Untuk menjadi seorang wirausaha mandiri, harus memiliki berbagai jenis modal. Ada tiga jenis modal utama yang menjadi syarat, yaitu: a. sumber daya internal calon wirausaha, misalnya kepandaian, keterampilan, kemampuan menganalisis dan menghitung risiko, serta keberanian atau visi jauh ke depan; b. sumber daya eksternal, misalnya uang yang cukup untuk membiayai modal usaha dan modal kerja, jaringan sosial serta jalur permintaan/penawaran, dan lain sebagainya; c. faktor X, misalnya kesempatan dan keberuntungan.

8. Memiliki Keberanian Menghadapi Risiko Seorang wirausaha harus berani menghadapi risiko. Semakin besar risiko yang dihadapinya, semakin besar pula kesempatan untuk meraih keuntungan. Mengapa demikian? Hal ini dikarenakan jumlah pemain semakin sedikit. Tentunya, risiko-risiko ini sudah harus diperhitungkan terlebih dahulu. Berani mengambil risiko yang telah diperhitungkan sebelumnya merupakan kunci awal dalam dunia usaha, karena hasil yang akan dicapai akan proporsional terhadap risiko yang akan diambil.

9. Selalu Mencari Peluang Seorang wirausaha sejati mampu melihat sesuatu dalam perspektif atau dimensi yang berlainan pada satu waktu. Bahkan, ia juga harus mampu melakukan beberapa hal sekaligus dalam satu waktu. Kemampuan inilah yang membuatnya piawai dalam menangani berbagai persoalan yang dihadapi oleh perusahaan. Semakin tinggi kemampuan seorang wirausaha dalam mengerjakan berbagai tugas sekaligus, semakin besar pula kemungkinan untuk mengolah peluang menjadi sumber daya produktif.

10. Memiliki Jiwa Kepemimpinan Untuk dapat mampu menggunakan waktu dan tenaga orang lain mengelola dan mengembangkan bisnisnya, seorang wirausaha harus memiliki kemampuan dan semangat untuk mengembangkan orang-orang di sekelilingnya. Seorang pemimpin yang baik tidak diukur dari berapa banyak pengikut atau pegawainya, tetapi kualitas orang-orang yang mengikutinya serta berapa banyak pemimpin baru di sekelilingnya.

11. Memiliki Kemampuan Manajerial Kemampuan manajerial seseorang dapat dilihat dan tiga kemampuan, yaitu: (1) Kemampuan teknik, (2) Kemampuan pribadi/personal, dan (3) Kemampuan emosional. Seorang wirausaha yang cerdas harus mampu menggunakan tenaga dan waktu orang lain untuk mencapai impiannya.

12. Memiliki Kemampuan Personal Semua orang yang berkeinginan untuk menjadi seorang wirausaha harus memperkaya diri dengan berbagai keterampilan personal.

13. Kreativitas dan Inovasi Kreativitas dan inovasi merupakan dua hal yang sangat penting dalamkewirausahaan. Kemampuan wirausaha dalam menerapkan konsep kreativitas dan inovasi merupakan salah satu kunci keberhasilan sebuah usaha, karena dengan kreativitas dan inovasilah para wirausaha akan mampu menciptakan produk-produk atau jasa-jasa yang unik dan kompetitif.

\section{METODE}

Penilitian ini menggunakan pendekatan metode pentelitian deskriptif kualitatif, bahwa penelitian kualitatif dilakukan karena peneliti ingin mengeksplor fenomena-fenomena yang tidak dapat dikuantifikasikan yang bersifat deskriptif (Satori, 2011). Penelitian deskriptif kualitatif ditujukan untuk mendeskripsikan dan menggambarkan fenomena yang ada, baik bersifat alamiah ataupun rekayasa manusia, yang lebih memperhatikan mengenai karakteristik, 


\section{sosio e-kons}

Volume 10, No. 2, Agustus 2018, pp. 165-178

e-ISSN: 2502-5449

p-ISSN: 2085-2266

http://journal.lppmunindra.ac.id/index.php/sosio_ekons

kualitas, keterkaitan antar kegiatan. Selain itu penelitian ini tidak memberikan perlakuan, manipulasi atau pengubahan pada variable-variabel yang diteliti, melainkan menggambarkan suatu kondisi yang apa adanya (Sukmadinata s., 2011). Teknik pengumpulan data bersumber pada data sekunder sedangkan instrument penelitian memanfaatkan hasil penelitian yang telah dilakukan baik itu bersumber dari Jurnal, Internet maupun buku.

\section{HASIL DAN PEMBAHASAN}

Kemampuan dan ketrampilan kewirausahaan seseorang itu tergantung pada kemampuan seseorang dalam mengatasi ketakutan dalam dirinya yang sebenarnya tidak ada. Kemampuan kewirausahaan itu dibagi berdasarkan tingkatan dalam mengatasi rasa takut akan kegagalan atau kesulitan yang seseorang hadapi. Beberapa hal dibawah akan menjelaskan hasil riset mengenai tingkat kemampuan wirausahawan dalam mengatasi risiko hingga menjadi wirausahawan yang sukses.

Dalam buku Cracking Entrepreneurs, inilah para crackers local yang tak ada matinya, (Kasali, 2012), membahas satu persatu-satu para entrepreneurs' yang memiliki tingkat kemampuan kewirausahaan dimana lebih condong kepada Risk Calculation Taker, antara lain:

Sanin-Berkah garam bagi seorang tukang becak-. Pak Sanin adalah seorang Risk Calculation Taker. Sepuluh tahun bertekun mengayuh becak tak membuat sanin menyerah begitu saja terhadap nasib. Keringat yang mengucur akhirnya mengkristal bagai garam. Asinnya garam membuat kehidupan sanin tak lagi hambar. Bisnis usahanya tidak atau belum dikelola secara organisasional. ya seperti inilah manajemen UMKM (Usaha Mikro, Kecil dan Menengah). Tumbuhnya perlahan-perlahan secara alamiah. Dan hanya mereka yang tekun, jujur, serta disiplinlah yang mampu bertahan dan tumbuh.

H. Darjat-Raja bengkel di Pelabuhan Ratu-. Jalan di Pelabuhan Ratu, Jawa Barat yang tidak mulus ternyata mendatangkan berkah bagi pria ini. Ketiga bengkelnya menguasai sepanjang jalan di kawasan tepi laut yang dikuasai dongeng Nyi Roro Kidul. Kisah sukses pria ini membuat decak kagum. Ayah dari 6 anak ini memulai usahanya dengan menjadi nelayan sejak tahun 1970, yang kemudian berkembang menjadi bisnis pengangkutan ikan ke Jakarta hingga ke luar negeri. Dari bisnis ikan inilah dia bisa membangun 3 (tiga) bengkel besar, yang kini beroleh omzet Rp. 50 Juta setiap harinya. Kita dapat menemui dua jenis nelayan, yaitu nelayan yang mau berubah dan yang tidak mau berubah. Tentu saja kita juga temui tukang becak, sopir angkot, pemulung, tukang sate, petambak garam, dan banyak lagi profesi kerakyatan lainnya yang masuk dalam kedua kategori tadi. Sebagian besar yang kita temui adalah mereka yang stagnan, memeluk selimut rasa aman, diam di tempat, tidak berubah. Malahan mereka semakin miskin, tua, renta dan tergusur. Mereka yang mau berubah mengubah nasib dari rakyat jelata menjadi kelas menengah mandiri. Namun untuk keluar dari perangkap masa lalu itu, seseorang pertama-tama harus mengubah cara berpikirnya dulu. Selama cara berpikirnya sama, maka tindakannya pun akan tetap sama.

Eddy Permadi-Energi yang menciptakan kemandirian ekonomi. Melepaskan pekerjaan tetap sebagai dosen bukan berarti duduk berpangku tangan. Dengan modal sendiri, mesin turbin mikrohidronya tak hanya menghasilkan energy, tetapi juga berbagai minuman serbuk, seperti bandrek. Perpaduan yang aneh memang, tetapi inilah UMKM dengan segmen keunikannya. Seniman-seniman UMKM seperti ini biasanya menggunakan Survival Instinct, naluri untuk bertahan atau beradaptasi. Mereka bukanlah expansionist seperti pengusaha-pengusaha barat atau pengusaha-pengusaha dari Asia Timur. Mereka mudah puas kalau cash flow nya aman dan produknya selalu ada pesanan. Survival Instinct, perlu digunakan setiap 6 bulan pertama, pesanan turbin tidak besar. Mereka butuh pekerjaan. Namun kalau UMKM ingin maju, mereka harus berefleksi dan berhenti berkreasi barang sejenak. 


\section{sosio e-kons}

Volume 10, No. 2, Agustus 2018, pp. 165-178

e-ISSN: 2502-5449

p-ISSN: 2085-2266

http://journal.lppmunindra.ac.id/index.php/sosio_ekons

Iyus Rohana Chandra-Menjadi sahabat para petani-. Berlokasi di lereng Pegunungan Patuha, perjalan UD Sahabat Tani, membuktikan bahwa di desa pun terdapat pemuda yang mampu berkembang menjadi wirausaha tangguh. Benar !, seorang wirausaha mengubah masalah menjadi peluang. Jadi masalah adalah peluang. Terbayang sekarang ada jutaan peluang di sector pertanian, mulai dari soal benih, pupuk alternative, logistic, pengolahan (off farming), permodalan, fasilitas pertanian, pengetahuan, lahan dan seterusnya. Ini berarti dibutuhkan kreativitas dan kejelian membaca peluang. Melihat saja tidak cukup. Untuk menangkap peluang ini, Anda harus menjadi "sahabat" petani dalam arti yang sesungguhnya: menyelami masalah dan hidup ditengah-tengah mereka. Sebabnya action. Betul, dibutuhkan action, ringan tangan bergerak. Sebab masalahnya begitu kompleks, sehingga menggunakan table cost-benefit saja bisa membuat wirausaha mengurungkan niatnya berpartisipasi. Terlalu banyak cost ketimbang benefitnya. Tetapi itu terjadi bila anda menggunakan paradigma yang lama. Anda perlu bertindak untuk mengubahnya, menciptakan system atau cara baru, bahkan produk-produk baru yang cost nya lebih rendah. Sebab masalah di sector pertanian adalah masalah cost. Dan ini berarti butuh inovasi. UD Sahabat Tani saja berhasil menangkap peluang dalam skala desa. Kuncinya hanya satu: Bagiamana mengubah sejuta masalah itu menjadi kesempatan emas agar para petani kembali menjadi subjek, menjadi pahlawan.

Sama halnya Dalam Buku Wirausaha Muda Mandiri (Kasali, 2010), membahas tingkat kemampuan kewirausahaan Cuma buku ini membahas kepada Wirausaha muda, dimana antara lain:

Henky Eko Sriyantono, Pemilik Bakso Malang Kota "Cak Eko", Hampir setiap tahun ia berpindah jenis bisnis, mulai dari aksesori berupa tas dan dompet, busana muslim, barang kerajinan, hingga mobil, tapi belum satu pun ia menemukan produk yang tepat untuk ia geluti. Semuanya merugi sebabnya sangat bermacam-macam. Antara lain, jenis produk tertentu tidak tepat menyasar target market tertentu. Tak hanya itu, Eko juga sempat ditipu. Namun, asa belum putus di benaknya. Mulailah ia terjun bebas di dunia makanan. Pria yang biasa disebut cak Eko ini membangu usaha catering rumahan, Namun gagal. Ia coba membeli waralaba makanan ringan tapi keuntungan yang diimpikan tak kunjung dating. Sempat pula ia mencoba menjual bandeng tanpa duri. Henky Eko Sriyantono mengalami jatuh bangun mengecap kegagalan hingga 10 kali ketika memulai bisnisnya. Baru setelah berusah selama 8 tahun, Henky Eko mulai menemukan kemandiriannya stelah merintis usaha Bakso Malang Kota "Cak Eko" di rumahnya di daerah Jatiwarana, Bekasi. Pada 2006, Eko menawarkan system franchise melalui website, yang segera mendapatkan sambutan positif. Saat ini Bakso Malang Kota"Cak Eko" sudah mempunyai 85 cabang di seluruh Indonesia. Dengan kemampuan merekrut pekerja sebanyak 300-400 orang, omzet ke 85 cabang di seluruh Indonesia bisa mencapai 1,6 - 2 miliar perbulan.

Terus berlanjut Tingkat kemampuan kewirausahaan terkhusus pada Risk Calculation Taker yang dirangkum(Brilio.net, 2018) dimana antara lain:

Hendri Setiono, Pemilik sekaligus pendiri PT Baba Rafi Indonesia (Bisnis Waralaba kuliner dari Indonesia). Meskipun pernah di tantang oleh orang tuanya, dan pernah kolaps karena uangnya dibawa lari oleh karyawannya, hal tersebut tak menyurutkan semangat dari seorang hendy untuk kembali mengambil kesempatan berbisnis.

Nadiem Makarim, Go-Jek di dirikan oleh Nadiem Makariem tak begitu saja mulus tanpa hambatan. Sebelumnya G0-Jek pernah menjadi 'Zombie' di bisnis yang Nadiem jalankan karena tak menemukan investor. Namun, kini Go-Jek menjadi salah satu rising star di bidang transportasi Indonesia. Apa salah satu factor pendukung kesuksesan Go-Jek?, program aplikasi mobile yang diluncurkan pada awal 2015 menjadi booming di social media, terus berkembang dan banyak diunduh oleh warga Jakarta yang sangat melek teknologi. Aplikasi mobile Go-Jek berhasil memberikan kemudahan bagi masyarakat disana mengingat pemberi jalan transportasi roda dua ini berhasil menjadi pilihan transportasi instan di tengah kemacetan Jakarta. 
William Tanuwijaya. Pendiri Tokopedia ini pernah bingung dan merasa gagal ketika banyak penipuan yang dilakukan penjual ke pembeli di sitenya yakni Tokopedia.com namun hal tersebut tak membuat William menyerah untuk terus mengembangkan dan menginovasi Tokopedia kea rah yang lebih baik lagi.

Akhmad Khoirul Alvi. Usaha untuk mengembangkan kerupuk kedelai tanpa kendala. Tahun lalu tempat usaha kerupuk kedelai yang terletak sekitar 100 meter dari rumahnya, kebakaran. Untung tak seluruh barang dagangannya ludes terbakar. Si jago merah masih menyisakan separuh dari kerupuk kedelai yang ada di gudangnya. "Untuk melanjutkan usaha kerupuk kedelai saya harus utang ke bank, tapi alhamdullilah sekarang sudah berjalan dengan baik lagi". Kepiawaian alvi dalam mengelola usaha membuat usahanya ini bangkit lagi. Kini, setiap bulannya Alvi memproduksi 4 ton kerupuk kedelai mentah. Kerupuk kedelai buatannya itu dipasarkan dengan harga Rp. 40.000 per $5 \mathrm{Kg}$.

Khalid Mustofa. Kisah inspirasi ini bisa kamu jadikan pelajaran. Berawal dari kegagalan bisnis ayam, membuat Khalid Mustofa, warga desa Plosorejo, Blitar, Jawa Timur, beralih ke biji kakao. Sempat mengalami pasang surut, akhirnya dia berhasil mendirikan sebuah tempat pengolah cokelat yang diberi nama kampong coklat. Usahanya ini sekarang memiliki omzet yang cukup fantastis. Baru 10 bulan berdiri omzetnya sudah Rp 60 juta/hari. Sedangkan pengunjungnya antara 500-600 orang pada hari biasa, tetapi kalau weekend bisa mencapai 4.000 -6.000 orang.

Anton Setiawan. Dengan modal Rp. 10 juta, hasil patungan dengan tiga temannya, Anton mengawali bisnisnya pada 2002. Ia menjual pulsa dengan system online, sayangnya, tiga bulan pertama, ia bangkrut karena tak bisa menutup biaya operasional. Pria asal Purwokerto, Jawa Tengah, itu mungkin juga tak pernah menyangka bahwa jalan hidupnya penuh dengan lika-liku dan tantangan. Jatuh bangun Anton membangun bisnis-bisnisnya. Mental yang kuat pun akhirnya mengantarkan menjadi pengusaha sukses. Kini bersama istrinya, Anton mengelola lima babyshop berlabel bebelove. Ia juga melayani penjualan grosir online beragam produk perlengkapan bayi dan mengirimkannya ke seluruh Indonesia. Pelanggannya mencapai belasan ribu, omzet yang dikantongi pun mencapai miliaran rupiah setiap bulan.

Achmad Zaky. Founder bukalapak ini awalnya membuka usaha pertama yaitu bisnis mie yang ia jalankan di tahun keduanya berkuliah dengan uang simpanannya dari hadiah memenangkan kompetisi computer. Ia ingin menjual mie dengan harga terjangkau untuk mahasiswa. Namun akhirnya ia menutup usaha tersebut. Namun ia tidak menyerah. Tahun berikutnya, Zaky memanfaatkan kemampuan komputernya untuk mendirikan sebuah software house bernama Deft Technology. Timnya memenangkan Indosat Innovation Wireless Contest pada tahun 2007 dan memperoleh penghargaan "merit winner" (juara kedua) di Indonesia ICT Awards (INAICTA) setahun kemudian. Tim tersebut mendirikan Bukalapak sebagai proyek sampingan mereka. Awalnya Bukalapak dimaksud untuk menjadi portofolio untuk ditunjukan kepada klien. Namun Bukalapak sekarang telah berkembang pesat dan mempunyai nilai transaksi lebih dari Rp. 500 juta per hari.

Syaputra Kamandanu Sofwan. Siapa sangka kalau pria kelahiran Tasikmalaya ini sekarang menjadi salah satu anak muda yang memiliki usaha yang sukses. Dan kerennya lagi danu mencoba mengangkat minuman tradisional Indonesia yaitu cendol dalam usahanya yang dinamai Randol (Raja Cendol). "Saya ngak mau ngikutin tren yang sudah ada karena saya akan ketinggalan, akhirnya setelah observasi mencuatlah nama cendol yang ternyata belum banyak yang tahu kalau cendol masuk minuman terlezat di dunia. Akhirnya saya niat membuat cendol kembali dilirik oleh masyarakat lagi. Tapi tentu saja kesuksesan ini tidak dapat dengan mudah. Sebelum Tahun 2014, Danu mulai bisnis cendol, dia pernah mencoba lebih dari 10 usaha lain yang ternyata tidak berjalan dengan baik, seperti berjualan pakaian, sepatu, parfum dan lainnya dimana semuanya dimulai pada tahun 2008.

Gaan Azka Ghafara. Bangkrut 2 (dua) kali tak menyebabkan Gazan patah semangat, dia pun mulai tertarik merambah ke kripik pisang. "Jadi awalnya itu saya lagi melamun terus 
kepingin makan keripik pisang lampung yang terkenal itu, tapi karena jauh jadi malas", ungkap Gazan. "Setelah itu saya survei teman-teman saya, mereka sebenarnya suka dengan keripik pisang tapi karena jauh lokasinya membuat mereka juga malas membeli, dari situ saya melihat peluang. Dengan modal awal hanya Rp. 50.000, Gazan nekat membeli keripik pisang dan bereksperimen dengan bumbu-bumbu kekini-kinian seperti bubuk coklat. Ditambah dengan uang hasil pinjaman dari tantenya sebesar Rp. 1.000.000,- Gazan mulai berani memproduksi keripik pisang buatannya. Kalau untuk keripik pisangnya sendiri saya ambil dari supplier, baru sampai di saya itu dibumbui dengan aneka jenis rasa seperti cokelat, susu, greentea, balado dan barbeque, tambah Gazan. "Alhumdullillah omsetnya sampai sejauh ini terus naik, terakhir bulan Maret kemarin mencapai Rp. 300.000.000,-“.

Disamping itu ada beberapa jurnal yang juga membahas mengenai Transformasi kewirausahaan dimana lebih mengarah pada Pola Pikir \& Paradigm serta Visioner (Inovasi \& Kreatif) antara lain:

\section{Transformasi kewirausahaan Pola Pikir \& Paradigm}

Penelitian ini menunjukan bahwa responden yang mempunyai motivasi tinggi, mempersepsikan hambatan pada kategori tinggi berupa tenaga kerja dan kompetisi serta pada kategori sedang adalah finansial, ekonomi dan teknologi, manajerial, infrastruktur, korupsi dan kejahatan, serta lokasi dan jaringan dalam pertumbuhan usaha. Penulis menyarankan agar pengusaha mikro dan kecil dapat menyadari dan meningkatkan motivasi yang ada pada diri mereka. (Ardi et al., 2014)

Hasil penelitian lain juga menguatkan, Prodi Administrasi Bisnis Telkom University angkatan 2011 secara keseluruhan sudah berminat untuk berwirausaha sebesar 95, 4\%. Dengan rincian mahasiswa sudah berminat untuk berwirausaha tetapi belum memulainya sebesar 63 , $9 \%$, mahasiswa yang sudah berminat dan memiliki usaha sebesar $16,9 \%$, dan mahasiswa yang sudah berminat dan menjalankan usaha tetapi gagal sebesar 14, 6\%. Hanya 4, 6\% yang belum berminat. Hasil lain ditemukan bahwa motivasi mahasiswa Prodi Administrasi Bisnis angkatan 2011 Telkom University untuk berwirausaha secara keseluruhan termasuk dalam kategori tinggi dengan rata-rata skor total sebesar 73, 63\%. Motivasi berwirausaha yang paling besar adalah ingin memiliki usaha sendiri, ingin mengimplementasikan ide dan inovasi, dan dan ingin memperoleh penghasilan atau pendapatan yang lebih baik.(Uswaturrasul \& Sisilia, 2015)

Hasil penelitian lain menemukan, Motivasi dan semangat kerja sangat memberikan pengaruh yang sangat besar terhadap minat wirausaha seseorang khususnya para mahasiswa.(Alim, 2013)

Penelitian lain, memberikan kesimpulan 1. Hasil penelitian ini menunjukkan bahwa dalam berwirausaha mereka telah memiliki visi dan tujuan yang jelas, mereka selalu berorientasi ke masa depan. Karena memiliki pandangan yang jauh ke depan, ia selalu berusaha untuk berkarsa dan berkarya serta menciptakan sesuatu yang baru, ia berusaha mencari peluang dan tantangan dan ia tidak cepat puas dengan yang sudah ada sekarang. 2. Wirausahawan adalah orang yang memiliki daya nalar intelektual yang tinggi. Apabila telah mengetahui sesuatu, ia tidak mengenal berhenti untuk belajar dan selanjutnya ingin mencboa dan terus mencoba. Di sinilah perpaduan yang nyata antara kemauan dan kemampuan yang mendorong seseorang untuk memiliki rasa ingin mencoba, tidak lain karena ia mau dan mampu serta sebaiknya mampu dan mau mencobanya.(NP, 2012)

Penelitian lain, menunjukan bahwa motivasi telah dibagi menjadi dua bagian yaitu internal dan eksternal dimana telah disimpulkan yaitu variabel internal dengan item kebutuhan akan kebebasan sebesar 57,8\%, untuk fator eksternal yaitu item lingkungan sosial ekonomi sebesar 53,3\%. Untuk variabel motivasi dengan item esteem needs sebesar 53.3\% dan variabel minat berwirausaha dengan item esteem needs sebesar 58.5\%. Sedangkan untuk hipotesis 1 dan II diterima, jadi secara simultan dan parsial variabel ekternal, internal dan motivasi berpengaruh terhadap minat mahasiswa berwirausaha.(Purwanto \& Sugiono, 2017) 
Penelitian lain, pengaruh utama dalam membangun minat untuk berwirausaha mahasiswa adalah pengetahuan tentang kewirausahaan yang dimiliki mahasiswa tersebut. Sampel penelitian ini adalah sampel jenuh, yaitu jumlah populasi sama dengan jumlah sampel. Responden adalah mahasiswa konsentrasi kewirausahaan dari tahun 2010-2013 yang berjumlah 33 orang.(Hadiyati \& Gajayana, 2012).

Paparan penelitian lain dalam motivasi berwirasusaha disimpulkan sebagai berikut: Ada pengaruh signifikan pengetahuan kewirausahaan terhadap minat berwirausaha dan ada pengaruh tidak langsung pengetahuan kewirausahaan terhadap minat berwirausaha melalui self efficacy sebesar 17,2\% (2) Ada pengaruh signifikan Motivasi belajar terhadap minat berwirausaha dan ada pengaruh tidak langsung motivasi belajar terhadap minat berwirausaha melalui self efficacy sebesar 15,3\% (3) Ada pengaruh signifikan status sosial ekonomi orang tua terhadap minat berwirausaha dan ada pengaruh tidak langsung status sosial ekonomi orang tua terhadap minat berwirausaha melalui self efficay sebesar $16,8 \%$ (4) Ada pengaruh signifikan self efficacy terhadap minat berwirausaha.(Jailani \& Sudarma, 2017)

Hasil penelitian bahwa motivasi usaha berpengaruh signifikan dan berbanding lurus (positif) terhadap kemampuan usaha, semakin tinggi motivasi usaha akan diikuti tinggi kemampuan usaha. Kemampuan usaha berpengaruh signifikan dan berbanding lurus (positif) terhadap keberhasilan usaha, semakin tinggi kemampuan usaha akan diikuti tinggi keberhasilan usaha. Selanjutnya pengaruh motivasi usaha terhadap keberhasilan usaha melalui variabel kemampuan usaha sebagai mediasi signifikan atau dapat diterima, sehingga motivasi usaha berpengaruh terhadap keberhasilan usaha melalui kemampuan usaha.(Gemina, Silaningsih, \& Yuningsih, 2016)

Dalam penelitian lain, Faktor-faktor motivasi minat mahasiswi disimpulkan antara lain: 1. Keberhasilan diri memiliki pengaruh positif dan signifikan terhadap motivasi mahasiswa perempuan dalam berwirausaha. Keberhasilan diri yang lebih besar yang diperoleh mahasiswi dapat meningkatkan motivasi dalam berwirausaha. 2. Toleransi akan resiko memiliki pengaruh positif dan signifikan terhadap minat atau motivasi mahasiswi dalam berwirausaha. Toleransi yang besar terhadap resiko akan berpengaruh terhadap motivasi dalam berwirausaha. 3 . Kebebasan melakukan pekerjaan memiliki pengaruh positif dan tidak signifikan terhadap motivasi mahasiswi dalam berwirausaha, maka bisa dikatakan tidak ada pengaruh yang signifikan. Bisa diambil kesimpulan bahwa kebebasan belum memberikan dorongan mahasiswi untuk memutuskan berwirausaha.(Irawati \& Hati, 2014)

Penelitian lain juga memaparkan mengenai motivasi dalam meningkatkan kemampuan usaha yaitu, hubungan antara variable motivasi usaha, kemampuan usaha dan keberhasilan usaha. Dari hasil pengujian ini menunjukkan bahwa motivasi usaha dengan indikator motif (keinginan pengusaha untuk berusaha), harapan (kesempatan yang diperoleh karena tercapainya tujuan usaha) dan insentif (imbalan yang diperoleh karena menjalankan usaha) berpengaruh positif terhadap kemampuan usaha dan keberhasilan usaha. Sedangkan kemampuan usaha (melalui indikator pengetahuan, sikap, keteramplilan dan kematangan emosional) berpengaruh positif terhadap keberhasilan usaha Industri kecil (dengan indikator efisiensi produksin dan perluasan produksi). Dalam pengaruhnya terhadap keberhasilan usaha variabel kemampuan usaha lebih dominan pengaruhnya terhadap keberhasilan usaha dibandingkan dengan motivasi usaha. Untuk itu perlu meningkatkan keberhasilan usaha industri kecil melalui kemampuan usaha dengan lebih mendahulukan meningkatkan sikap, kecerdasan emosional, keterampilan dan pengetahuan para pengusah industri kecil dalam melakukan usahanya dan juga motivasi usaha dengan lebih mendahulukan meningkatkan harapan, motifasi dan insentif.(Purnama, n.d.)

\section{Visioner (Inovasi \& Kreatif)}

Penelitian lain bahwa kreativitas dan inovasi mempunyai pengaruh dalam aktivitas berwirausaha yaitu, 1.Kreativitas dan inovasi berpengaruh signifikan secara silmutan terhadap pemasaran kewirausahaan pada usaha kecil Keramik Dinoyo Malang. 2. Kreativitas dan inovasi 


\section{Sosio e-kons}

Volume 10, No. 2, Agustus 2018, pp. 165-178

e-ISSN: $2502-5449$

p-ISSN: 2085-2266

http://journal.lppmunindra.ac.id/index.php/sosio_ekons

berpengaruh signifikan secara parsial terhadap pemasaran kewirausahaan pada usaha kecil Keramik Dinoyo Malang. 3. Kreativitas berpengaruh dominan terhadap pemasaran kewirausahaan pada usaha kecil Keramik Dinoyo Malang. (Hadiyati \& Gajayana, 2012)

Penelitian lain juga mengupas mengenai Hubungan kreativitas, Efikasi diri dan Intensi berwirausaha pada mahasiswa dimana disimpulkan yaitu: (1) terdapat hubungan yang signifikan antara kreativitas dengan in- tensi berwirausaha mahasiswa FE UNJ; (2) terdapat hubungan yang signifikan antara efikasi diri dengan intensi berwirausaha mahasiswa FE UNJ, dan (3) terdapat hubungan yang signifikan antara kreativitas dan efikasi diri terhadap intensi berwirausaha mahasiswa FE UNJ.(Ponco, Karyaningsih, \& Wibowo, 2017)

Penelitian lain juga mengekspos kreativitas dan inovatif di kalangan industri dimana disimpulkan yaitu: Kreatifitas dan inovatif merupakan dua faktor yang sangat penting dan menjadi modal dasar bagi setiap pengusaha terutama pada fase pembukaan usaha baru dan senantiasa ditingkatkan, dapat dilakukan melalui mengunjungi industri sejenis di wilayah lain, melakukan evaluasi dan perbaikan atas produk yang sudah ada, menganjurkan bagi setiap elemen dalam usaha untuk membuka pikiran dan mengikuti perkembangan industri sejenis melalui Internet. Industri kreatif perlu karena terus dikembangkan terutama di Kota Pekanbaru, sehingga daya kreatifitas juga keinovatifan perlu ditingkatkan sehingga menjadi lem perekat dalam keberlanjutan usaha. (Sri Zuliarni, 2014)

Penelitian juga mengupas mengenai inovasi dan kreativitas di sekolah dimana disimpulkan yaitu: Pengembangan kreativitas dan inovasi sebagai basis kewirausahaan sekolah merupakan ikon baru bagi kepala sekolah bersama warga sekolah. Kewirausahaan sekolah dipahami sebagai kernarnpuan kreatif dan inovatifyang dijadikan dasar, kiat dan sumber daya untuk mencari dan memanfaatkan peluang menuju sukses.(Surya Dharma, 2009)

\section{SIMPULAN}

Berdasarkan hasil analisis yang dilakukan mengenai Perspektif tingkat kemampuan wirausahawan merubah risiko menjadi sukses berwirausaha antara lain:

1. Dari banyak pengalaman wirausahawan yang dijalankan, tingkatan kemampuan wirausahawan lebih condong pada risk calculation taker atau berani mengambil risiko usaha dengan perhitungan aman. Dimana tingkat kemampuan kewirausahaan dalam menghadapi rasa takutnya lebih tinggi dan memiliki keberanian untuk menanggung atau mengatasi risiko kegagalan. Berani menghadapi rasa takutnya karena ia merasa mampu, memiliki pengetahuan dan pengalaman kerja yang sesuai dengan apa yang ia kerjakan dalam bisnisnya.

2. Transformasi kewirausahaan merubah risiko menjadi kesuksesan dalam beberapa penelitian lebih condong kepada Pola Pikir dan Paradigma serta Visioner (Inovasi dan Kreatif) dibandingkan pada variable owner dan investor.

3. Dari 10 penelitian yang menyangkut motivasi kesimpulannya lebih mengarah pada kesuksesan dalam melakukan wirausaha.

4. Dari 4 penelitian yang mengyangkut visioner (inovasi dan kreatif) lebih mengarah pada kesuksesan dalam melakukan wirasuaha

\section{SARAN}

1. Risiko apapun mengenai hambatan dalam melakukan kegiatan kewirausahaan selaku akan mengalami banyak perubahan di masa akan datang, penelitian merupakan bagian kunci penting guna membantu dalam memecahkan permasalahan risiko atau hambatan dalam melakukan kegiatan kewirausahaan 


\section{Sosio e-kons}

Volume 10, No. 2, Agustus 2018, pp. 165-178

e-ISSN: 2502-5449

p-ISSN: 2085-2266

http://journal.lppmunindra.ac.id/index.php/sosio_ekons

2. Untuk menjadi wirausahawan yang sukses, risiko sudah menjadi bagian dari kehidupan kegiatan kewirausahaan atau dengan kata lain wirausahawan harus dapat merubah risiko menjadi kesuksesan

3. Variabel tranformasi kewirausahaan khsususnya pada owner dan investor menjadi tantangan khsususnya dalam melakukan penelitian lebih lanjut dalam menyangkut segi risiko bertransformasi menjadi kesuksesan berwirausaha.

\section{DAFTAR RUJUKAN}

Alim, M. C. (2013). Motivasi Dan Semangat Kerja dengan Berwirausaha bagi Mahasiswa Mohammad Cipto Alim Dosen Fakultas Ekonomi Universitas Islam Madura. Wacana Equiliberium No.1 Des 2013, 1(1), 88-102.

Ardi, S., Ardianti, R., Bisnis, P. M., Manajemen, P. S., Petra, U. K., \& Siwalankerto, J. (2014). Entrepreneurial Motivation Dan Persepsi Terhadap Sektor Formal Di Jawa Timur. AGORA, 2(1).

Brilio.net. (2018). 10 pebisnis ini sempat gagal sebelum akhirnya sukses besar. Retrieved from www.brilio.net

Bukalapak, K. (2014). Apa yang Ingin Anda Cari Tahu? Beberapa hambatan atau kendala Wirausaha pada umumnya from https://komunitas.bukalapak.com/s/supomk/beberapa_hambatan_atau_kendala_wirausaha _pada_umumnya

Gemina, D., Silaningsih, E., \& Yuningsih, E. (2016). Pengaruh motivasi usaha terhadap keberhasilan usaha dengan kemampuan usaha sebagai variabel mediasi pada industri kecil menengah makanan ringan priangan timur-Indonesia. Jurnal Manajemen Teknologi, 15(3), 297-323.

Hadiyati, E., \& Gajayana, U. (2012). Kreativitas dan inovasi pengaruhnya terhadap. jurnal inovasi dan kewirausahaan, 1(3), 135-151.

Hendro. (2011). Dasar-dasar kewirausahaan: panduan bagi mahasiswa untuk mengenal, memahami dan memasuki dunia bisnis. Jakarta: Erlangga.

Irawati, R., \& Hati, S. W. (2014). Faktor-Faktor yang Memotivasi Minat Mahasiswi dalam Berwirausaha di Politeknik Negeri Batam. Jurnal Ekonomi Pendidikan Dan Kewirausahaan, 2(April).

Jailani, M., \& Sudarma, K. (2017). Pengaruh kewirausahaan , motivasi belajar , sosial ekonomi orang tua dan self efficacy terhadap minat berwirausaha siswa. Journal of Economic Education, 6(1), 52-59.

Kasali, R. (2010). Wirausaha muda Mandiri. Jakarta: Gramedia.

Kasali, R. (2012). Cracking Entrepreneurs, inilah para crackers local yang tak ada matinya. Jakarta: Gramedia.

NP, M. G. W. E. (2012). Analisis faktor-faktor motivasi berwirausaha terhadap keberhasilan pengusaha UKM (studi pada UKM kota Malang). Profit, Volume 6 No. 1 Juni 2012, 1(1), $50-53$.

Ponco, R., Karyaningsih, D., \& Wibowo, A. (2017). Hubungan Kreativitas , Efikasi Diri dan Intensi Berwirausaha pada Mahasiswa. Jurnal Pendidikan Ekonomi \& Bisnis, 5(2), 162 175.

Prof Dr. Sama'un Jaja Raharja. (2008). Dasar pola pikir kewirausahaan dan wirausaha. Jakarta: Universitas Terbuka (UT).

Purnama, C. (n.d.). Motivasi dan kemampuan usaha dalam meningkatkan keberhasilan usaha industri kecil ( Studi pada industri kecil sepatu di Jawa Timur ). Jurnal Manajemen Dan Kewirausahaan, 12(2), 177-184. 


\section{Sosio e-kons}

Volume 10, No. 2, Agustus 2018, pp. 165-178

e-ISSN: $2502-5449$

p-ISSN: 2085-2266

http://journal.lppmunindra.ac.id/index.php/sosio_ekons

Purwanto, N., \& Sugiono, D. (2017). Pengaruh faktor internal, eksternal dan motivasi dan terhadap minat berwirausaha pada mahasiswa juruasan akuntansi ( Studi Mahasiswa STIE Malangkucecwara Malang ). Jurnal Dinamika Dotcom no.2 Juli, 8, 87-97.

Rahmidani, R. (2014). Analisa faktor penghambat berwirausaha pada pengrajin sulaman wanita di Jorong Lundang Kanagarian Panampuang Kabupaten Agam. Kajian Manajemen Bisnis, Vol.3.

Satori. (2011). Metode penelitian kualitatif. Bandung: Alfabeta.

Sri Zuliarni. (2014). Analisis kreatifitas dan inovatif pengusaha industri kreatif sub sektor kerajinan di Pekanbaru. Jurnal Aplikasi Bisnis, 4(2), 110-123.

Sukmadinata s., nana. (2011). Metode penelitian pendidikan. Bandung: PT Remaja Rosakarya.

Surya Dharma, H. A. (2009). Kewirausahaan sekolah berbasis kreativitas dan inovasi. Jurnal Pendidikan Dan Kebudayaan, 15(1), 102-117.

Uswaturrasul, Y., \& Sisilia, K. (2015). Analisis Minat Dan Motivasi Berwirausaha Mahasiswa ( Studi Pada Program Studi Administrasi Bisnis Telkom University Angkatan 2011 ) Analysis Of Student' S Entrepreneurial Intention And Entrepreneurial Motivation ( A Study On Business Administration Study. In e-Proceeding of Management: Vol.2, No.3 Desember 2015 (Vol. 2, pp. 3586-3596). 